(Uniwersytet Warszawski, e-mail: m.wojtynska-no@uw.edu.pl)

ORCID 0000-0002-4450-7802

\title{
ANTYSEMITYZM W POLSKIEJ PRASIE DWUDZIESTOLECIA MIEDZYWOJENNEGO. LEKSYKA NAGEÓWKÓW PRASOWYCH TYGODNIKA „POD PRĘGIERZ”
}

Zgodnie $z$ tytułem przedmiotem niniejszego artykułu jest przedstawienie wyników analizy leksykalnej wybranych nagłówków prasowych pochodzacych $z$ tygodnika „Pod Pręgierz. Pismo Poświęcone Obronie Handlu i Przemysłu Chrześcijańskiego w Wielkopolsce". Czasopismo ukazywało się w latach 1929-1939. Trzeba zaznaczyć, że od 1934 r. gazeta często zmieniała podtytuł, a w roku 1939 zmianie uległ tytuł pisma na „Pręgierz: Pismo Antyżydowskie, Poświęcone Obronie Handlu, Przemysłu i Rzemiosła Chrześcijańskiego: Poznań, Warszawa, Kraków, Sosnowiec, Katowice, Bydgoszcz, Gdynia, Radom, Lublin". Gazeta była tygodnikiem ilustrowanym, wydawanym w Poznaniu przez Leona Kuliga. W 1939 r. osiagnęła nakład 25 tysięcy egzemplarzy ${ }^{1}$ i powiększyła zasięg kolportażu daleko poza Wielkopolskę, co skwapliwie uwypuklono w podtytule. Teksty zamieszczane na łamach tygodnika wpisuja się w krag tematyczny związany $z$ antysemityzmem, a walka $z$ Polakami żydowskiego pochodzenia koncentruje się na polu życia handlowego i gospodarczego Drugiej Rzeczypospolitej.

Na podstawę materiałową niniejszej analizy złożyło się 1637 nagłówków prasowych zamieszczonych w 106 numerach czasopisma. ${ }^{2}$ Wybór wymienionych pozycji został podyktowany dostępnościa materiałów - tylko te egzemplarze przetrwały zawieruchę wojenną i zachowały się do naszych czasów. W kwestii formalnej należy wskazać, że termin nagłówek przyjęłam za W. Pisarkiem w znaczeniu 'wydrukowany tytuł (wraz $z$ ewentualnymi nadtytułami i podtytułami) wypowiedzi, działu lub ru-

1 J.B. Michlic, Obcy jako zagrożenie. Obraz Żyda w Polsce od roku 1880 do czasów obecnych, Warszawa 2015, s. 164.

${ }^{2} Z$ roku 1933 pochodziło 25 numerów, $z$ roku $1934-26$, z roku $1935-25$, z roku 1936 - 1, z roku 1937 - 14 i z roku 1939 - 16 numerów. Wszystkie numery poddane ekscerpcji dostępne sa $\mathrm{w}$ formie zdigitalizowanej na stronach: https://polona.pl/search/?query=pod_pr\%C4\%99gierz\&filters=public: 1 oraz https://polona.pl/search/?query=pr\%C4\%99gierz\&filters=public: 1 - stan na dzień 01.01.2020 r. 
bryki w czasopiśmie'. ${ }^{3}$ Odmiennie jednak niż W. Pisarek nagłówek wieloczłonowy potraktowałam jako jednostkę i nie wyróżniłam w jej obrębie tytułu głównego, któremu towarzyszy nadtytuł albo i nadtytuł, i podtytuł. Ponadto $z$ analizy wyłączyłam śródtytuły, czyli nagłówki poszczególnych części artykułu.

$\mathrm{Na}$ wstępie trzeba zaznaczyć, że tytuł jest jednym $z$ najmniejszych tekstów pojawiających się w publikacjach prasowych i jednocześnie jest tekstem najistotniejszym. ${ }^{4}$ Przypisane sa bowiem do niego bardzo ważne funkcje: przede wszystkim nagłówek ma w sposób skrótowy powiadamiać czytelnika o treści wypowiedzi, a $z$ drugiej strony ma być tym bodźcem, który ma zachęcać odbiorcę do zapoznania się $z$ treścią artykułu. ${ }^{5} \mathrm{~W}$ ścisłej korelacji $z$ tym podziałem pozostają dwa typy nagłówków, a mianowicie te, którymi opatrzone sa wypowiedzi informacyjne, oraz te, które nazywaja wypowiedzi publicystyczne. Pierwszy typ ma za zadanie streszczenie wypowiedzi, dlatego przyjmuje formę krótkiego oznajmienia, w którym dominuje słownictwo neutralne stylistycznie. Drugi typ jest bardziej urozmaicony, często nawiązuje do stylistyki języka mówionego, a nawet potocznego, jego celem zaś jest wskazanie głównej myśli wypowiedzi, a podstawową funkcja - zachęcenie odbiorcy do zapoznania się $z$ treścia tekstu. ${ }^{6}$

Należy wskazać, że na kartach tygodnika „Pod Pręgierz” odnotowałam obecność obu typów nagłówków, choć przeważa typ publicystyczny. $Z$ punktu widzenia ukształtowania składniowego dominują nagłówki jednozdaniowe, które stanowią aż 87\% (czyli 1429 ) wyekscerpowanych jednostek - w tym zaś zbiorze nieznacznie dominuja wypowiedzi rozwinięte, w skład których wchodzą więcej niż trzy wyrazy (58\%, czyli 834 jednostki). Nagłówków wielozdaniowych jest 13\% (czyli 208), niejednokrotnie sa bardzo rozbudowane i stanowia sui generis streszczenie artykułu, przejmując tym samym funkcję nagłówków śródtekstowych. Ukierunkowanie informacyjne jest w nich tak duże, że czytelnik może poprzestać tylko na zapoznaniu się $z$ ich treścia, a następnie przejść do kolejnych artykułów prezentowanych na łamach tygodnika.

Uwzględniając perspektywę pragmatyczną, która w wypadku analizowanych jednostek językowych koncentruje się na wzbudzaniu zainteresowania czytelnika przedstawianym mu tekstem, trzeba wskazać, że zadanie to najlepiej wypełniają nagłówki w formie zdań pytających i rozkazujacych, gdyż te schematy składniowe ułatwiaja prowadzenie gry

3 W. Pisarek, Poznać prasę po nagłówkach! Nagłówek wypowiedzi prasowej w oświetleniu lingwistycznym, Kraków 1967, s. 4-5.

4 M. Ślawska, Tytut - najmniejszy tekst prasowy, „Rocznik Prasoznawczy” 2008, II, s. 117.

5 A. Markowski, O tytułach publikacji prasowych, „Prasa Techniczna” 1977, nr 3, s. 25.

6 Encyklopedia wiedzy o prasie, red. J. Maślanka, Wrocław 1976, s. 244. 
językowej między autorem tekstu a czytelnikiem. ${ }^{7} \mathrm{~W}$ czasopiśmie „Pod Pręgierz" zdecydowanie przeważają zdania oznajmujące, których jest aż 87\% (czyli 1 431). Nagłówków sformułowanych w trybie rozkazującym jest 6,6\% (czyli 108), w formie pytajnej zaś 5,7\% (czyli 93), w postaci zdania kończącego się dwoma znakami interpunkcyjnymi (?!) jest 0,3\% (czyli 5). Charakterystyczne dla gazety jest to, że nagłówki o strukturze rozkazujacej i pytajnej zamieszczane były na stronie tytułowej. Czyniono tak w celach perswazyjnych, gdyż odwoływały się one nie do wiedzy czytelnika, lecz do sfery emocji, uprzedzeń i stereotypów. Pierwsze odgrywały rolę apeli - wzywały czytelników do walki w imię obrony zagrożonych interesów finansowo-gospodarczych chrześcijańskiego świata. Drugie - najczęściej przybierały postać aitiologii, która polega na zadawaniu pytań i udzielaniu na nie odpowiedzi. ${ }^{8}$ Większość pytań zakładała niewiedzę odbiorcy, dlatego odpowiedzią na nie była treść artykułu, która jednocześnie zawierała wskazówki dotyczące pożądanego - czyli antysemickiego - kierunku myślenia i postępowania.

Zarysowanej powyżej funkcji pragmatycznej nagłówków całkowicie podporządkowana została pełniona przez nie funkcja estetyczna, która zazwyczaj sprowadzała się do uatrakcyjnienia wyglądu zewnętrznego kolumn i sposobu ich rozmieszczenia. ${ }^{9} \mathrm{~W}$ tygodniku "Pod Pręgierz” głównym celem szaty graficznej nagłówków było absorbowanie uwagi czytelnika i koncentrowanie jej na prezentowanej treści. Wszystkie nagłówki wydrukowane zostały czcionką pogrubiona. Rozmiar czcionki jest urozmaicony; częste są wypadki, że nagłówek rozpoczyna się czcionką bardzo duża, a kończy średnią bądź mała. Duża i bardzo duża czcionka zarezerwowana jest dla strony tytułowej. Poza tym stosowane sa wersaliki, podkreślenia, druk rozstrzelony oraz łączenie liter $\mathrm{w}$ danym słowie za pomoca dywizu, np. $\dot{Z}-y-d-y, N-a-r-e-s-z-c-i-e$.

Podsumowując omówiona kwestię, trzeba stwierdzić, że kształtowi składniowemu i graficznemu nagłówków przyświecał wyraźny cel pragmatyczny: wzbudzanie zainteresowania treścią artykułu, która koncentrowała się na wezwaniu do wzięcia czynnego udziału w walce $z$ mniejszością żydowska. Jako pole walki - zgodnie $z$ tematyka pisma - obrano dziedzinę handlu.

W tym miejscu spójrzmy na nagłówki $z$ punktu widzenia analizy statystycznej części mowy. Uzyskane przeze mnie rezultaty potwierdziły ustalenia dokonane przez W. Pisarka w latach sześćdziesiatych

7 D. Długosz, Tytuł prasowy - Analiza lingwistyczna. Na materiale wybranych artykułów „Gazety Wyborczej” $z$ lat 2007-2010, „Zeszyty Tarnowskiego Towarzystwa Naukowego" 2013, nr 2, s. 26-27.

8 K. Kłosińska, R. Zimny, P. Żukiewicz, 2018, Sprawozdanie ze stanu ochrony języka polskiego za lata 2016-2017 - Język informacji politycznej, http://www.rjp.pan.pl, s. 30.

9 W. Pisarek, op. cit., s. 8. 
XX wieku, które sprowadzały się do stwierdzenia, że nagłówki stanowią „krańcowy przykład stylu nominalnego”. ${ }^{10} \mathrm{~W}$ materiale leksykalnym gazety „Pod Pręgierz” dominowały rzeczowniki (co ilustruje poniższa tabela). Ich udział wraz pozostałymi imiennymi częściami mowy (także $z$ imiesłowami przymiotnikowymi, których odnotowałam 68) przyjął wartość $79 \%$.

Tabela 1. Układ rangowy struktury części mowy słownictwa nagłówków czasopisma „Pod Pręgierz”

\begin{tabular}{|l|c|c|c|c|}
\hline \multicolumn{1}{|c|}{ Część mowy } & $\begin{array}{c}\text { Liczba } \\
\text { leksemów }\end{array}$ & $\begin{array}{c}\text { Udzial } \\
\text { [\%] }\end{array}$ & Liczba użyć & $\begin{array}{c}\text { Udzial } \\
\text { [\%] }\end{array}$ \\
\hline rzeczownik & 1704 & 60,9 & 4024 & 47,5 \\
\hline czasownik & 515 & 18,4 & 1084 & 12,8 \\
\hline przymiotnik & 358 & 12,8 & 1083 & 12,8 \\
\hline przysłówek & 66 & 2,4 & 127 & 1,5 \\
\hline zaimek & 43 & 1,5 & 459 & 5,4 \\
\hline liczebnik & 31 & 1,1 & 62 & 0,7 \\
\hline partykuła & 30 & 1,1 & 283 & 3,3 \\
\hline przyimek & 27 & 1,0 & 1111 & 13,1 \\
\hline spójnik & 15 & 0,5 & 238 & 2,8 \\
\hline cytat* & 4 & 0,1 & 5 & 0,1 \\
\hline wykrzyknik & 4 & 0,1 & 4 & 0,0 \\
\hline RAzEM & $\mathbf{2 7 9 7}$ & $\mathbf{1 0 0 , 0}$ & $\mathbf{8 4 8 0}$ & $\mathbf{1 0 0 , 0}$ \\
\hline
\end{tabular}

* W wyekscerpowanym materiale odnotowałam cytaty w postaci wyrażeń i sentencji, dlatego wyodrębniłam je jako oddzielną pozycję.

W zakresie rzeczowników 26\% zbioru stanowią nazwy własne (imiona i nazwiska lub tylko nazwiska, nazwy firm, miejscowości, ulic, państw, tytuły czasopism), które przez W. Pisarka określane były jako wyrazy niezależne od autora, czyli zdeterminowane przez rzeczywistość pozajęzykowa. ${ }^{11} \mathrm{Za}$ tak dużym nasyceniem nagłówków nazwami własnymi przemawia funkcja informacyjna, która w czasopiśmie „Pod Pręgierz” jest ściśle podporządkowana funkcji perswazyjnej, mającej na celu stygmatyzację obywateli pochodzenia żydowskiego oraz Polaków ich wspierających. W nagłówkach osoby te poddawane sa identyfikacji, czyli zamieszczane sa ich imiona, nazwiska i nierzadko adresy zamieszkania,

11 W. Pisarek, op. cit., s. 11. 
co czynione jest po to, by następnie w treści artykułu nawoływać czytelników do ich napiętnowania i wykluczenia $z$ życia zarówno społeczno-gospodarczego, jak i kulturalnego. To samo dotyczyło prowadzonych przez Żydów firm, do bojkotu których radykalny tygodnik antysemicki wzywał w każdym numerze.

Warto także spojrzeć na wyekscerpowany materiał leksykalny $z$ punktu widzenia frekwencji wyrazów. Dane statystyczne dowodzą, że wyraźnie przeważają wyrazy użyte tylko jeden raz (ponad 66\%). Największą grupa wśród hapax legomena sa rzeczowniki, z których aż 348 jest nazwami własnymi (18,8\% tej grupy); gdybyśmy ich nie uwzględnili, to stosunek leksemów użytych tylko raz kształtuje się następujacco: rzeczowniki 44\%, czasowniki 19\%, przymiotniki 13,5\% i pozostałe części mowy 4,9\%. Nie można zaprzeczyć, że taki rozkład częstości użyć niewątpliwie świadczy o różnorodności słownictwa.

Tabela 2. Układ rangowy struktury częstości słownictwa nagłówków czasopisma „Pod Pręgierz”

\begin{tabular}{|c|c|c|c|c|c|c|c|c|}
\hline Część mowy & 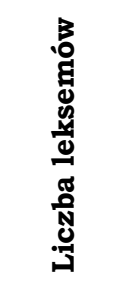 & 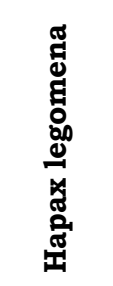 & 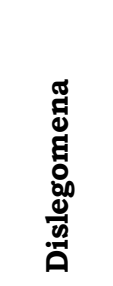 & 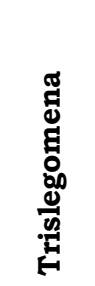 & 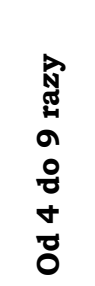 & 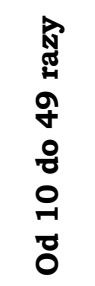 & 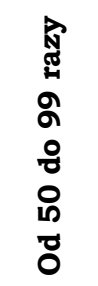 & 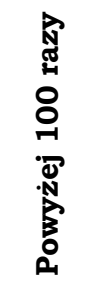 \\
\hline rzeczownik & 1704 & 1159 & 267 & 99 & 134 & 41 & 3 & 1 \\
\hline czasownik & 515 & 353 & 71 & 38 & 42 & 10 & 1 & 0 \\
\hline przymiotnik & 358 & 250 & 52 & 14 & 34 & 6 & 1 & 1 \\
\hline przysłówek & 66 & 39 & 14 & 4 & 9 & 0 & 0 & 0 \\
\hline zaimek & 43 & 8 & 3 & 7 & 13 & 12 & 0 & 0 \\
\hline liczebnik & 31 & 20 & 5 & 2 & 4 & 0 & 0 & 0 \\
\hline partykuła & 30 & 10 & 7 & 2 & 4 & 6 & 0 & 1 \\
\hline przyimek & 27 & 6 & 2 & 1 & 4 & 9 & 2 & 3 \\
\hline spójnik & 15 & 1 & 3 & 1 & 6 & 3 & 0 & 1 \\
\hline wykrzyknik & 4 & 4 & 0 & 0 & 0 & 0 & 0 & 0 \\
\hline cytat & 4 & 3 & 1 & 0 & 0 & 0 & 0 & 0 \\
\hline RAZEM & 2797 & 1853 & 425 & 168 & 250 & 87 & 7 & 7 \\
\hline UDZIAL & $100,0 \%$ & $66,4 \%$ & $15,2 \%$ & $6,0 \%$ & $9,0 \%$ & $3,1 \%$ & $0,3 \%$ & $0,3 \%$ \\
\hline
\end{tabular}


Przejdźmy teraz do rozpatrzenia nagłówków tygodnika $z$ perspektywy semantycznej. Ramy objętościowe niniejszego artykułu wymusiły skrótowe omówienie tego zagadnienia, dlatego za reprezentatywne dla wyekscerpowanego zasobu leksykalnego uznałam omówienie słów kluczy ${ }^{12}$ przez pryzmat najbardziej liczebnego kręgu tematycznego, w którym się one pojawiły.

Analiza ilościowa słownictwa wykazała, że jedynie sześć leksemów uzyskało frekwencję użyć powyżej 50 razy $(12,4 \%$ użyć na tle całości słownictwa), co ilustruje poniższa tabela. Zważywszy na tematykę gazety, trzeba stwierdzić, że wyrazem neutralnym stylistycznie jest jedynie rzeczownik firma (o najmniejszej frekwencji). Pozostałe słowa klucze sa natomiast nacechowane albo negatywnie (Żyd, żydowski) - i one dominują w omawianym zbiorze - albo pozytywnie (Polska, Poznań, polski).

Tabela 3. Układ rangowy słów kluczy nagłówków czasopisma „Pod Pręgierz”

\begin{tabular}{|l|c|c|}
\hline \multicolumn{1}{|c|}{ Słowa klucze } & Liczba użyć & $\begin{array}{c}\text { Udzial } \\
\text { [\%] }\end{array}$ \\
\hline Żyd & 466 & 44,3 \\
\hline żydowski & 315 & 30,0 \\
\hline Polska & 74 & 7,0 \\
\hline Poznań & 74 & 7,0 \\
\hline polski & 68 & 6,5 \\
\hline firma & 54 & 5,1 \\
\hline RAZEM & $\mathbf{1 ~ 0 5 1}$ & $\mathbf{1 0 0 , 0}$ \\
\hline
\end{tabular}

Materiał leksykalny tych nagłówków, które zawierały słowa klucze, pozwolił na wyodrębnienie 16 kręgów tematycznych, co przedstawia poniższa tabela.

12 Historię i znaczenie tego terminu przytacza E. Stachurski, Słowa-klucze polskiej epiki romantycznej, Kraków 1998, s. 12-13. W. Pisarek posługuje się terminem wyrazy-klucze, W. Pisarek, Poznać prasę..., s. 64. 


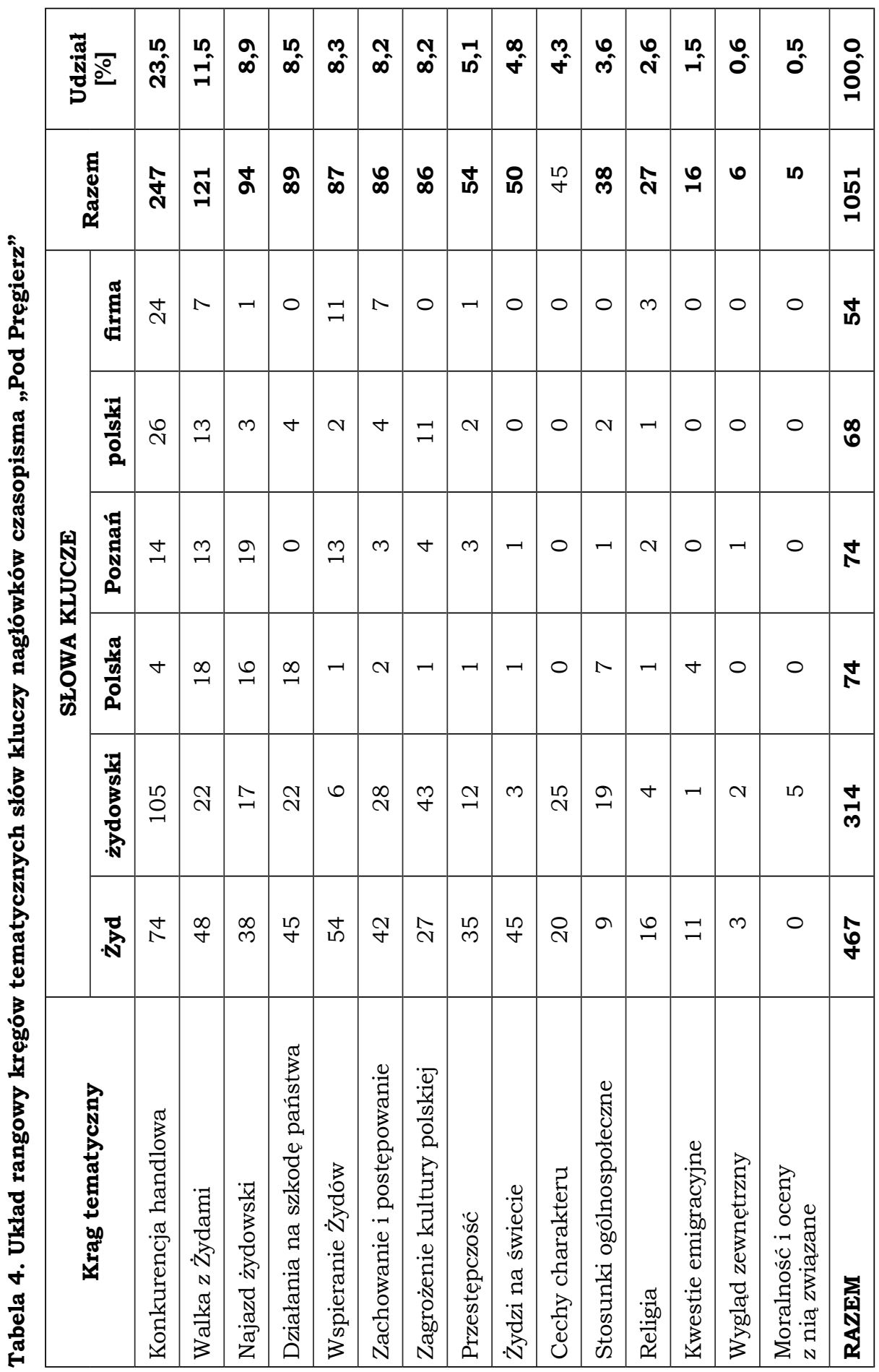


Jak widzimy, najbardziej liczebnym kręgiem jest $<$ Konkurencja handlowa> i właśnie temu zbiorowi przyjrzymy się bliżej. Rozpoczniemy od przeglądu stałych związków frazeologicznych, które odnosiły się do osób narodowości żydowskiej i prowadzonej przez nie działalności gospodarczej. Odnotowałam następujące frazeologizmy: iść po trupach (Żydzi ida po trupach), być $w$ czyichś rękach (Krawiectwo wojskowe $w$ Warszawie $w$ rękach żydów) ${ }^{13}$, wprowadzać kogoś $w$ bład (Reklama radiowa $i$ kupcy wprowadzaja $w$ błąd klientele), zalewać rynek (Żydzi zalewaja rynek wielkopolski i pomorski tandetnemu baterjami do lampek elektrycznych), wyjść na czymś (Jak wyszedł Jan Kiepura na żydowskiej reklamie), zbierać plon (Żydowskie biura reklamy zbieraja plon), ktoś, coś spod znaku czegoś (O firmie z pod znaku swastyki i żydowskiej gwiazdy), skończyć z czymś (Skończyć z żydowskimi przedstawicielami!), nie kijem go, tylko pałka (Nie kijem go tylko pałka), słodzić komuś życie (Kto nam "słodzi” życie żydowskimi czekoladami i cukierkami).

Obok wymienionych przykładów odnotowałam kilkanaście innowacji frazeologicznych: nie móc narzekać $\rightarrow$ nie móc naskarżyć się na coś (Żyd Bilski nie może sie skarżyć na zła koniunkturę), pod własnym dachem $\rightarrow$ pod polskim dachem (Żydowskie radioodbiorniki pod polskim dachem), stać za kimś $\rightarrow$ siedzieć za kimś (Za angielska firma siedzi żyd), $\dot{z} y c ́$ na czyjś koszt $\rightarrow$ żyć $z$ kogoś ( $Z$ kogo żyje żydek Wall), dostać się $w$ czyjeś szpony $\rightarrow w$ szponach czegoś (Warszawa $w$ szponach polipa; Poznanianki $w$ szponach żydowskich), coś jest woda na czyjś młyn $\rightarrow(\mathrm{Na}$ żydowski młyn...), wyrwać sie z czyichś rakk $\rightarrow$ wyrwać coś $z$ rakk żydowskich (Wyrwać handel zbożem z rakk żydowskich), dostać nauczke + nauka nie poszła $w$ las $\rightarrow$ (Oby nauczka nie poszła $w$ las!), stać na czele $\rightarrow$ kroczyć na czele (Na czele przemysłu mydlarskiego kroczy Firma "TUKAN"), poupychać, poutykać coś po katach $\rightarrow$ ukryć coś $w$ kacie (Żydostwo trudno ukryć nawet $w$ kacie).

Jak widać, dobór frazeologizmów nie jest przypadkowy: brak tu jednostek leksykalnych konotujących pozytywny obraz świata, a w tym wypadku - pozytywny obraz osób pochodzenia żydowskiego i ich działalności handlowej. Zaprezentowane jednostki leksykalne zaliczyć można do negatywnie nacechowanych frazeologizmów stylowych. Posłużyły one do przypisania Żydom ujemnych cech zarówno charakteru, jak i postępowania, takich jak: bezczelność, skłonność do oszustw, próba dominacji na rynku gospodarczym, intryganctwo, chciwość, zaborczość, działanie na swoja korzyść.

Do społeczności polskiej odnosi się zaledwie kilka związków frazeologicznych: stać na straży czegoś (Korporacja Kupców-chrześcijan stoi na straży polskiego handlu $w$ Gdyni), coś zmalało do zera (Gdy nie będzie polskich kupców detalistów-wytwórczość polska zmaleje do zera), z zasady ( $Z$ zasady nie kupuje u żyda), dopiać celu (Polak ułatwia żydowi

$13 \mathrm{~W}$ cytatach zachowuję oryginalna pisownię nagłówków. 
dopięcia celu), wziać kogoś na kieł (Weźmy ich na kiet!), być wzorem dla kogoś (Gdy żyd ma być wzorem dla Polaka). Odnotowałam dwie innowacje frazeologiczne: brać, wziać coś pod rozwage $\rightarrow$ pod rozwage (Prasie poznańskiej $i$ kupcom polskim pod rozwage); oddać komuś serce $\rightarrow$ czyjeś serce bije z miłości do kogoś (Od czterech tygodni bije serce Nawrockiego $z$ miłości ku synom Izraela). Trudno nie zauważyć, że i w tym zbiorze brak jest pozytywnie nacechowanych jednostek leksykalnych - przeważają frazeologizmy epatujące czytelnika treściami zagrożenia, ostatni zaś $z$ wymienionych przykładów jest przesycony ironią i drwina.

W składzie wyekscerpowanych związków frazeologicznych brak jest archaizmów czy wyrazów przestarzałych. Ze względu na najniższy odsetek analfabetyzmu w dawnym zaborze pruskim tygodnik „Pod Pręgierz" był pismem adresowanym do szerokiego ogółu, który obejmował wszystkie warstwy społeczne. ${ }^{14}$ Autorzy artykułów posługiwali się językiem nieoficjalnym, pełnym ekspresywizmów, bliskim ówczesnej potocznej odmianie polszczyzny mówionej. Przytoczone przeze mnie dość liczne innowacje frazeologiczne można uznać za celowe kreacje artystyczne, raczej niewysokich lotów, których celem była gra językowa prowadzona z czytelnikiem często o niewysokim poziomie wykształcenia.

W kręgu <Konkurencja handlowa> możemy wyodrębnić cztery podzbiory. Pierwszy $z$ nich zawiera określenia osób, a jego struktura jest wyraźnie biegunowa. Negatywne postrzeganie świata żydowskiego wyrażone zostało leksemami, z których duża część jest neutralna znaczeniowo, a które otrzymały ujemne zabarwienie pod wpływem kontekstu. Sa to przede wszystkim nazwy członków społeczności żydowskiej, które odnoszą się do: pochodzenia etnicznego (Żyd, żydostwo, żydek, synowie Izraela), wykonywanego zawodu (futrzarz żydowski, kupiec, przedstawiciel, przemysłowiec żydowski), udziału w życiu handlowym (akcjonariusze żydzi, konkurentka, rywal, wróg, „łapacz”, plaga kupiectwa polskiego, polip, „wspólnicy” polskiej poczty). Warto dodać, że rzeczowniki Żyd, Żydówka, Żydek pisane sa zawsze mała litera, co jest dowodem na postrzeganie tych nazw jako ujemnie nacechowanych, a co służy deprecjonowaniu omawianej mniejszości etnicznej. Ponadto przy wymienianiu osób pochodzenia żydowskiego podawane sa tylko ich nazwiska, pomijane sa imiona (np. żyd Bilski) oraz zwroty grzecznościowe pan, pani, które zarezerwowane sa dla osób pochodzenia polskiego. Drugim zbiorem sytuującym się na biegunie nagłówków niosących pejoratywne wartościowanie sa określenia osób niebojkotujących przedsiębiorczości żydowskiej, nieżywiących uprzedzeń wobec Żydów oraz otwarcie wspierających tę grupę społeczna. Najwięcej jest tu nazw identyfikujących osoby dokonujące zakupów w sklepach żydowskich, co ma na celu stygmatyzację tych osób lub grup społecznych, których są przedstawicielami (oficer, elegantka, ko-

14 M.K. Jeleniewski, Obraz Żyda i Niemca $w$ prasie międzywojennej Wielkopolski, Bydgoszcz 2015, s. 7. 
lejarz, obywatelstwo pleszewskie, rezerwiści, poznańskie sfery towarzyskie, Polki, pocztowcy, „poznańscy” przemysłowcy, właściciele domów). Osoba pomagająca Żydom to szabesgoj, pogardliwie nazywana także $p a-$ chołkiem, ironicznie zaś spółka (żydzi i spółka). Słownictwo o pozytywnych konotacjach stanowi grupa, w której występuja określenia Polaków (robotnik, elegant, drobny kolonialista, polski kupiec detalista, polski chatupnik, polski piekarz, kupiec prowincjonalny). Warto zwrócić uwagę na to, że zarysowany układ biegunowy omawianego zbioru jest wynikiem stosowania zarówno wartościowania systemowego, jak i używania identyfikatora $\mathrm{w}$ postaci przymiotników polski, żydowski, które na łamach pisma "Pod Pręgierz" sa wyraźnie nacechowane. Stąd zestawiane z rzeczownikiem neutralnym stylistycznie narzucają mu określone wartościowanie.

Leksemy, które ukonstytuowały drugi podzbiór, stricte obrazuja zagadnienie konkurencji handlowej. W centrum znalazło się słownictwo opisujące metody stosowane w handlu przez Żydów, np.: brudne metody $\dot{z} y d o w s k i e ~ w$ handlu, sztuczki $i$ szacherki, Żyd każe sobie dwukrotnie płacić za towar, niegodziwe metody żydowskiej konkurencji, nieuczciwa $\dot{z} y d o w s k a$ konkurencja, żydowskie monopole $w$ handlu, dziwnie tania $\dot{z} y d o w s k a$ nafta, taniość żydowska, przekupstwo, przedstawiciel wyszkolony po żydowsku, forsować wyroby żydowskie, bojkot polskich hurtowni, Jak wyzyskuja żydzi polskich chałupników, kombinacja, oszukańcza afera, tajniki żydowskiego handlu, tajemnica, koniunktura, zamaskowane żydowskie składy obuwia. Tutaj mieszczą się także działania marketingowe przedstawiane jako zagrożenie dla polskiego kupiectwa: tryk reklamowy, lawina żydowskich prospektów reklamowych, reklama radiowa, ogłoszenia żydowskie, żydowskie ulotki, reklama pożyczkowa, sabotaż (To jest wyraźny sabotaż. Żydowska reklama pożyczkowa $i$ jej wyniki), żydowskie biura reklamy. Trzeba podkreślić, że piętnowanymi metodami marketingowymi posługiwała się także sama redakcja czasopisma „Pod Pręgierz”, gdyż każda ostatnia strona gazety przeznaczona była na zamieszczanie reklam sklepów chrześcijańskich.

Wyraźnie zaznacza się grupa określeń obrazujących próbę przejęcia polskiego rynku handlowego przez mniejszość żydowską: zalew żydowski polskich rynków mydlarsko-kosmetycznych, Żydzi zalewaja rynek wielkopolski, wykupuja systematycznie wszystko co polskie, importerzy owoców obsadzaja wszystkie placówki żydami, gwałtowny napór żydowskich fabrykantów, rywalizować zawzięcie z Polakami, opanować w 99 procentach, handel owocami południowymi opanowany, niszczyć, zagrażać bytowi drobnych kolonialistów, okupacja Starego Rynku przez $\dot{z} y d o ́ w$, atak żydów, podczas jarmarków zjeżdża się ich cała falanga, niebezpieczeństwo żydowskie.

$\mathrm{W}$ omawianym zbiorze obecne sa zwroty zwiazane $z$ dokonywaniem transakcji: płacić Żydowi, Żyd: pośredniczy, kupuje towar u Polaków, urzadza sprzedaże, handluje wszystkim, podwyższa cene (Pomarańcze staniały a żydzi podwyższają na skrzyni o 10 złotych). 
Dosyć liczny jest zbiór leksemów odnoszacy się do działów handlowych oraz produktów handlowych. Przede wszystkim odzwierciedla on wyraźnie zarysowana, uproszczona, bo dychotomiczna, wizję świata, w którym to, co dobre, sygnalizowane jest użyciem przymiotnika chrześcijański, a to, co złe - przymiotnika żydowski. Dominuje tu postrzeganie negatywne, co przejawia się przede wszystkim w stałej enumeracji produktów żydowskich, których ilość wydaje się nieskończona, np.: $\dot{z} y$ dowskie fabrykaty; dewocjonalia; mięso, sacharyna, owoce południowe, śledzie, żydowskie piwo, wino mszalne, żydowskie wino, sól, pomarańcze, czekolady, cukierki, żydowskie koniaki, niepolskie drożdże, szynka, świąteczne strucle $z \dot{z} y d o w s k i e j$ maki; mundur, futro, obuwie, kapelusze, dodatki do kapeluszy, czapki, pończochy, włóczka żydowska, nici, tasiemki, kilimy, torebki; mydło, wyroby mydlarskie, ostrza do golenia; radioodbiorniki, baterie do lampek elektrycznych, lampki na groby; materiały budowlane, forniery, drzewo, żydowskie piecyki, żydowska nafta; narty, petardy, żydowskie tutki do papierosów; żydowskie opony, części samochodowe, części rowerowe, wyroby gumowe, opony i dętki. Celem wyliczeń jest bez watpienia ostrzeganie czytelnika przed kupnem tych rzeczy, o czym świadczą często pojawiające się przymiotniki: tani, tandetny, żydowski, nielegalny, nieczysty. Trzeba zaznaczyć, że leksem tani nie jest tu dodatnio nacechowany, gdyż przymiotnik ten użyty w odniesieniu do żydowskiego sklepu wprowadzał presupozycyjnie informację o złej jakości produktów.

Jeśli chodzi o branże handlowe, to najczęściej wymieniane sa: fabryki wódek, browary, wytwórnie win, krawiectwo wojskowe, branża radiowa, rybołówstwo, motoryzacja, poczta, handel drzewny, branża zegarmistrzowsko-jubilerska, handel zbożem, handel futrzany, rynki mydlarsko-kosmetyczne. Określenia związane $z$ handlem prowadzonym przez chrześcijan sa zawsze dodatnio nacechowanie i pojawiaja się w nagłówkach rzadko, co może służyć uwypukleniu rzekomo znikomej pozycji Polaków na tym polu w porównaniu $z$ zalewem i naporem handlu żydowskiego. Najczęściej używane są tu dwa przymiotniki: chrześcijański (maślanka, wyrób, kupiec-chrześcijanin, placówka finansowa; DROGOWSKAZ. Spis firm chrześcijańskich godnych polecenia $w$ Poznaniu) i polski (handel nabiałem, mennica, wydawnictwo pocztówek; polski towar $i$ tylko u Polaka). Znamienny i jakby tracący patetyzmem biblijnym jest rzeczownik drogowskaz, tu użyty w znaczeniu przenośnym.

Trzecim zbiorem sa nazwy odnoszace się do miejsca i czasu prowadzenia handlu przez Żydów: Żyd ulokowat się, rynek wielkopolski i pomorski, jarmark, centrum Poznania, skład żydowski, nielegalne fabryki, magazyn żydowski, sklep, skład obuwia, hurtownia, stragany żydowskie, salon samochodowy, składy drogeryjne; $w$ niedziele, okres przedgwiazdkowy, urzadza sprzedaże gwiazdkowe, wyładowuje towar przy udziale robotników $w$ niedzielę. Jako wysoce naganne postrzegane jest zwłaszcza prowadzenie handlu przez Żydów w niedzielę, która dla chrze- 
ścijan jest dniem świętym. Przywoływanie tej okoliczności służy wskazywaniu na odmienność zarówno religijna, jak i kulturową społeczności żydowskiej. Narzuca to identyfikację jej członków jako obcych pod względem religijnym, narodowym i politycznym (bezpaństwowcy), a to daje przyzwolenie na ich ekskluzję społeczna..

W sposób wyraźny uwidacznia się czwarty zbiór, który zawiera nagłówki obrazujące reakcję Polaków na zagrożenie płynące ze strony dominacji handlu żydowskiego. Obecne sa tu grupy wypowiedzeń będacych sui generis ostrzeżeniem: Co zyskała Galicja kupujac u żydów?, Gdy żyd ma być wzorem dla Polaka, Historia żydów poznańskich, Szczury spaceruja po wystawie żydowskiego sklepu $w$ Warszawie przy ul. Waski Dunaj, Akademicki Zw. Morski a niebezpieczeństwo żydowskie; wezwaniem do bojkotu i do walki: Nie będziemy konsumowali żydowskiego piwa, Przeczytaj i omijaj!, Robotnicy w Gdyni uchwalili wczoraj unikać sklepów żydowskich, Nie reklamować firm żydowskich, Nie jeździć na żydowskich oponach samochodowych, Opony i dętki tylko z fabryk chrześcijańskich, Popierajmy wyroby polskie, Polski towar i tylko u Polaka, Bojkotujmy żydowskie fabrykaty, Goracy apel redakcji, popierać wyłacznie polskie..., Nie kupuj u żyda!, Wyrwać handel zbożem z rąk żydowskich, Kupujac u żydów - wspomagasz swego wroga!, Zaprzestać kupowania towarów u żydów, a sami z Polski się wyniosa. Warto także wskazać grupę nagłówków identyfikujacych firmy i sklepy żydowskie oraz informujących o objęciu ich działalności wnikliwymi dochodzeniami, co presuponowało prowadzenie przez Żydów działalności niezgodnej z prawem: „Przewodnik katolicki” ogłasza firmy żydowskie, Uzupełniajacy spis firm $i$ składów żydowskich $w$ Poznaniu, Co pisze prasa o firmie Nachtigal, Reflektorem po źródłach żydowskiej taniości, Demaskujemy żydowskie fabryki mydła, Handel futrzany $w$ Polsce i jego tajemnice, Pytamy firme Cegielski.

Nie można pominąc leksyki, której funkcją było akcentowanie sukcesu polskiej strony w walce ze strona żydowską: Rozrost firmy St. Michałowski (oczywiście polskiej), Stwierdzamy to z radością. Polski Zwiazek Bokserski zerwał umowe $z$ żydowska firma (...), Żydowskie utrapienie $z$ szyldami (po wprowadzeniu obowiazku umieszczania na nich imion i nazwisk właścicieli) czy Torebki f-my Ka-Ri-Bi w śmietniku (oczywiście torebki produkcji żydowskiej), Likwidacja placówek żydowskich $w$ Poznaniu. Pojawiaja się tu nagłówki o wydźwięku wprost patetycznym: Czołowa Prasa Wielkopolska składa przysiege, że już nigdy ogłoszeń żydowskich zamieszczać nie bedzie! Cokolwiek wykona polska ręka - to musi znaleźć zbyt! Korporacja Kupców-chrześcijan stoi na straży polskiego handlu w Gdyni.

Rekapitulując przytoczone egzemplifikacje słownictwa, które wypełniło krag <Konkurencja handlowa>, należy wskazać, że najbardziej uwidacznia się nagromadzenie środków językowych o ujemnym nacechowaniu: zarówno leksyki, której definicje słownikowe zawierają odcień 
negatywny, jak i leksyki neutralnej stylistycznie, ale zestawianej w taki sposób, aby stała się nośnikiem wartościowania negatywnego.

W odniesieniu do wyekscerpowanego materiału leksykalnego trzeba zwrócić uwage na to, że wartościowanie negatywne przejawia się także w stosowaniu cudzysłowów, które nie sa używane jako znaki graficzne oznaczające cytowanie, lecz służą modyfikacji stylistycznej znaczenia danego słowa. Wyrazy zapisane w cudzysłowie, które znalazły się w nagłówkach, wnoszą do treści wypowiedzenia element ironii, drwiny, szyderstwa. Trzeba zaznaczyć, że w omawiany znak graficzny ujęte zostały słowa neutralne stylistycznie lub dodatnio nacechowane ( $z$ wyjatkiem pogardliwego rzeczownika geszeft) - w wypadku pierwszych analizowana operacja językowa polegała na ich semantycznej degradacji, a w wypadku drugich - na odwróceniu nacechowania: "geszeft”, "taniość, "tani”, „tańszy”, "chrzciny”, „słodzic”,, "rywale”, "chałupnik”, "metody handlowe”, „poznańscy” przemysłowcy, „polska” firma, "polska” fabryka, „wspólnicy" polskiej poczty.

Zabarwienie ironiczne obecne jest także w nagłówkach opartych na grze językowej. Autorzy artykułów wyzyskują do tego celu m.in. znaczenia przenośne leksemów, ich wieloznaczność, modyfikuja stałe zwiąki frazeologiczne, np.: Żydowskie nici łacza Warszawe z Poznaniem; Żydzi i spółka; Nie kijem go tylko pałka, „Chrzciny” magazynu żydowskiego „Wolwort”. Odnotowałam wypowiedzi o strukturze symetrycznego przeciwstawienia, np.: Chrześcijańska maślanka a żydowskie opony; Polscy piekarze... niepolskie drożḋ̇e; Żydowskie szynki w polskich żoładkach; Polacy zamknęli- żydzi otwieraja; Żydzi kupuja towar u Polaków a Polacy u żydów. Trzeba zaznaczyć, że w tygodniku „Pod Pręgierz” na ostatniej stronie poświęconej reklamie sklepów chrześcijańskich zawsze pojawiały się nagłówki o przeciwstawnej treści - jedne miały na celu zachęcanie do kupowania u swoich, drugie zaś miały być ostrzeżeniem przed zakupami w sklepach niechrześcijańskich: Żydowskie hurtownie części samochodowych, Chrześcijańskie hurtownie części samochodowych; Żydowskie fabryki czekolady i cukrów, Chrześcijańskie fabryki czekolady i cukrów, Ostrza do golenia polskiej produkcji, Żydowskie ostrza do golenia.

Podsumowując dotychczasowa analizę, należy stwierdzić, że nagłówki prasowe wyekscerpowane $z$ gazety „Pod Pręgierz” pomimo zróżnicowania składniowego i dużego bogactwa leksykalnego odzwierciedlają wizję rzeczywistości zredukowanej do dychotomicznego podziału na to, co dobre, czyli polskie, oraz na to, co złe, czyli żydowskie. W sposób niekwestionowany dominuja wypowiedzi zawierające negatywne wartościowanie osób pochodzenia żydowskiego oraz ich działań, co wyraża się w ogromnej dysproporcji ilościowej pomiędzy słownictwem dodatnio i ujemnie nacechowanym. Wartościowanie pozytywne pojawia się bardzo rzadko i jest ono zarezerwowane tylko dla Polaków chrześcijan. W przytoczonych przeze mnie egzemplifikacjach głównymi nośnikami negatywnego wartościowania językowego są leksemy prymarnie i sekundarnie nacechowane 
aksjologicznie. ${ }^{15}$ Zgromadzony przeze mnie materiał leksykalny ilustruje wszystkie jawne (krytyka i nagana, potepianie i osadzanie) i zakamuflowane (podejrzenie, posądzenie, pomówienie; kalumnia, oszczerstwo, potwarz; plotka; zdrada, denuncjacja, donos, anonim; dowcip i kawał; ironia) formy działań językowych wpisujących się w zjawisko agresji językowej. ${ }^{16}$ Poza warstwa leksykalna przejawia się ono w ukształtowaniu składniowym nagłówków (zwłaszcza w wyborze formy pytajnej bądź trybu rozkazujacego), w postaci graficznej (negatywne określenia pisane bywają czcionka pogrubioną i o dużym rozmiarze) oraz w kwestiach ortograficznych (pisownia rzeczownika $Z$ yd i rzeczowników pochodnych od tego leksemu mała litera). Użycie tego typu środków językowych na łamach czasopisma „Pod Pręgierz” wpisuje się w akty agresji językowej, gdyż było to działanie mające na celu wyrządzenie krzywdy mniejszości żydowskiej przez stygmatyzację, stereotypizację oraz przez nawoływanie do czynnej dyskryminacji jej członków. Było to zjawisko językowe tym bardziej szkodliwe, że w czasach 20-lecia międzywojennego prasa była środkiem masowego przekazu, a na terenie byłego zaboru pruskiego - ze względu na znikomy odsetek analfabetyzmu - była także szczególnie skutecznym narzędziem propagandowym.

\section{Bibliografia}

D. Długosz, 2013, Tytut prasowy - Analiza lingwistyczna. Na materiale wybranych artykułów „Gazety Wyborczej” z lat 2007-2010, „Zeszyty Tarnowskiego Towarzystwa Naukowego" nr 2.

M.K. Jeleniewski, 2015, Obraz Żyda i Niemca $w$ prasie międzywojennej Wielkopolski, Bydgoszcz.

K. Kłosińska, R. Zimny, P. Żukiewicz, 2018, Sprawozdanie ze stanu ochrony języka polskiego za lata 2016-2017 - Język informacji politycznej, http:// www.rjp.pan.pl

A. Markowski, 1977, O tytułach publikacji prasowych, „Prasa Techniczna” nr 3.

J. Maślanka (red.), 1976, Encyklopedia wiedzy o prasie, Wrocław.

J.B. Michlic, 2015, Obcy jako zagrożenie. Obraz Żyda w Polsce od roku 1880 do czasów obecnych, Warszawa.

M. Peisert, 2004, Formy i funkcje agresji werbalnej. Próba typologii, Wrocław.

W. Pisarek, 1967, Poznać prasę po nagłówkach! Nagłówek wypowiedzi prasowej $w$ oświetleniu lingwistycznym, Kraków.

E. Stachurski, 1998, Słowa-klucze polskiej epiki romantycznej, Kraków.

15 Klasyfikacja przejęta za: K. Kłosińska, R. Zimny, P. Żukiewicz, 2018, Sprawozdanie ze stanu ochrony języka polskiego za lata 2016-2017- Język informacji politycznej, http://www.rjp.pan.pl, s. 19.

16 M. Peisert, 2004, Formy i funkcje agresji werbalnej. Próba typologii, Wrocław, s. 16. 
M. Ślawska, 2008, Tytuł - najmniejszy tekst prasowy, „Rocznik Prasoznawczy” r. II.

https: / / polona.pl/search / ?query=pod_pr\%C4\%99gierz\&filters=public: 1 https://polona.pl/search/?query=pr\%C4\%99gierz\&filters=public: 1

\section{Antisemitism in the Polish press of the interwar period. Lexis of the newspaper headlines of the weekly titled „Pod Pręgierz" (“In the Pillory")}

\section{Summary}

This paper is dedicated to the lexical issues of the Polish language of the interwar period approached from the angle of language ethics. It represents the stream of structuralist research and has been prepared in accordance with the synchronic method. The author concentrates on describing selected aspects of the language of newspaper headlines. The object of the research paper is the lexical corpus of 106 issues representing 5 annals of a radical antisemitic weekly titled „Pod Pregierz" ("In the Pillory”). The outcome of the performed analysis of the vocabulary of headlines has shown that the dominance of the lexical linguistic measures which negatively evaluate the Jewish community fully fits the lexis of „Pod Pregierz” into the phenomenon of language aggression.

Keywords: antisemitism - language ethics - language aggression - language of newspaper headlines - structuralism - lexis - thematic circles of vocabulary - statistical method of studying vocabulary - keywords

Trans. Monika Czarnecka 